\title{
Microbial response to the presence of buried kimberlite pipes in the Attawapiskat region, northern Ontario; Bacteria-kimberlite interactions
}

\author{
Laura Donkervoort ${ }^{1}$ Stewart Hamilton $^{2}$ Dale Sutherland ${ }^{3}$ and Gordon Southam ${ }^{4}$ \\ ${ }^{1}$ The University of Western Ontario, London, Canada, ldonkervoort@srk.com \\ ${ }^{2}$ Ontario Geological Survey, Sudbury, Canada, stew.hamilton@ontario.ca \\ ${ }^{3}$ Activation Laboratories Ltd., Ancaster, Canada,dalesutherland@actlabsint.com \\ ${ }^{4}$ The University of Queensland, St. Lucia, Australia, g.southam@uq.edu.au
}

Introduction

Bacteria are active in surface and near surface environments and are the dominant group of organisms in the subsurface (Stevens and McKinley 1995; Stevens et al. 1993). In both envionments they are important catalysts of geochemical reactions where they can play a significant role in altering the permeability of geologic systems by dissolving and precipitating minerals, thus controlling fluid flow (Southam and Saunders 2005). The bacterial communities that can generate the most energy under a particular set of geochemical conditions will be enriched and will in turn alter their geochemical environment. Kimberlite exploration has traditionally involved the use of indicator minerals and geophysics. However, geochemical conditions 'produced' by kimberlite-water interactions have been identified as a potential tool in diamond exploration (Hattori and Hamilton 2008 refs). In these systems, bacteria-water-rock interactions (Wanger et al 2008) can enhance mineral weathering contributing to this geochemical signal.

\section{Analytical Results}

Jurassic kimberlites in the Attawapiskat region of the James Bay Lowlands, Canada, are intruded into Paleozoic carbonate rocks and covered by Holocene marine silts and extensive peat. These buried kimberlite pipes 'produce' geochemical conditions, e.g., increased $\mathrm{pH}$ and decreased $\mathrm{Eh}$, in overlying peat (Sadler et al 2011) that have selected for bacterial populations that are best able to grow and, which, in turn affect the geochemistry, producing a linked biogeochemical signal. The dispersion halo is characterized by abiotic-inorganic (Sadler et al 2011) \& organic markers and biotic, biogeochemical markers that are shown to complement the aqueous geochemical indicators of buried kimberlites i.e., increased $\mathrm{pH}$ and decreased $\mathrm{Eh}$, in near surface samples of peat.

A microbiological study of peat conducted over the Zulu kimberlite located in the Attawapiskat area demonstrated that limestone and sub-cropping kimberlite influenced the diversity and populations of microorganisms living in the overlying peat. Results of bacterial enumeration combined with biodiversity analysis demonstrate increased anaerobic populations and lower biodiversity directly above the kimberlite pipe, suggesting that the release of geochemical nutrients via water kimberlite interactions have selected for a subset of the overall bacterial population. Overall, the bacterial counts were higher across the Zulu transect when compared the control transect (Figure 1). The aerobic heterotrophs show a pattern of greater populations corresponding to the kimberlite edges, similar to the classic, 'rabbit ear' or edge effect pattern identified in the complementary, geochemcial survey (Sadler et al., 2011). In contrast, the anaerobic heterotrophs revealed a pattern of greater populations in samples directly overlying the kimberlite body. Ratioing anaerobes:aerobes, in order to account for heterogeneity of the substrate and variations in nutrient availability demonstrated an enrichment in anaerobic bacteria directly over the kimberlite as an apical pattern. Spatiotemporal Geochemical Hydrocarbons (Actlabs, SGH) demonstrated that the Zulu kimberlite was found to possess a wide range of high molecular weight organic compounds that intuitively, influenced the diversity and populations of the heterotrophic microorganisms living in the overlying peat. The observed SGH "halo" anomaly likely represents a strong REDOX cell, consistent with the methane production described by Sader et al. (2013). 

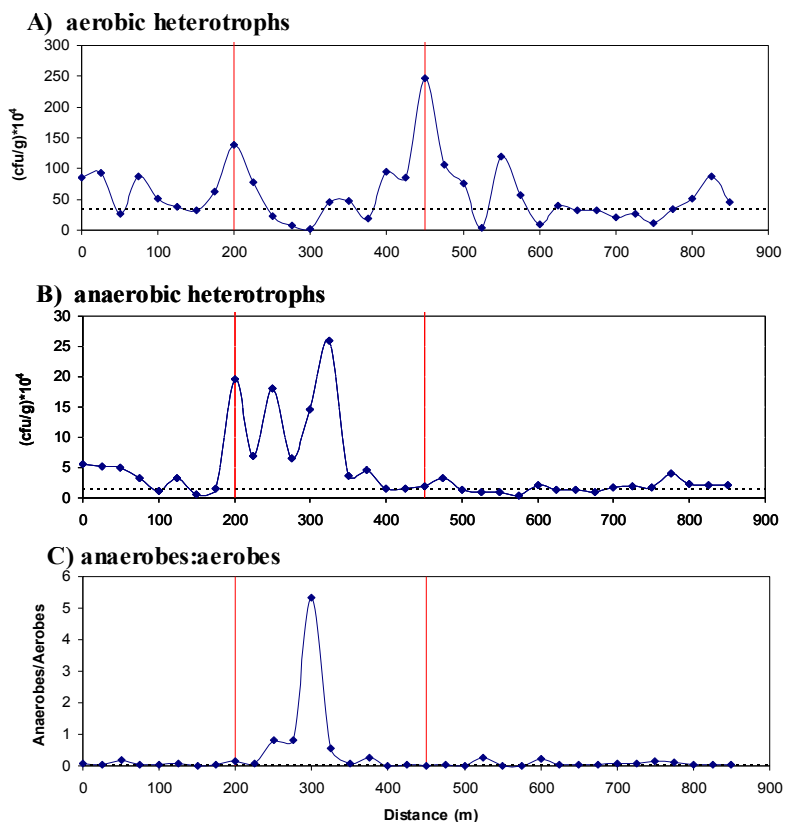

Figure 1 - Viable heterotophic spread plate counts (cfu/g), cultured from peat collected along the Zulu transect. (A) aerobic heterotrophs; (B) anaerobic heterotrophs; (C) ratio of anaerobic:aerobic heterotrophs. The dotted line indicates the average control population.

Using anaerobic microcosm experiments designed to replicate field conditions, and imaging with scanning electron microscopy, the Zulu kimberlite was shown to support significant bacterial growth. A sample of kimberlite collected from the Zulu occurrence was capable of supporting a lithotrophic (rock-eating) community of microorganisms (Figures 2 and 3). These natural, kimberlite associated bacteria, grew in a sterile distilled water-kimberlite system, demonstrating that the bacteria directly interacted with kimberlite and that kimberlite contains all of the essential nutrients required to support the growth of bacteria. After 2 months incubation, bacteria had colonized the entire surface of the kimberlite producing an evenly distributed bacterial population of $3.2 \times 10^{5}$ bacteria $/ \mathrm{cm}^{2}$ plus larger bacterial microcolonies highlighting active growth on select mineral substrates (Figure 2, inset).

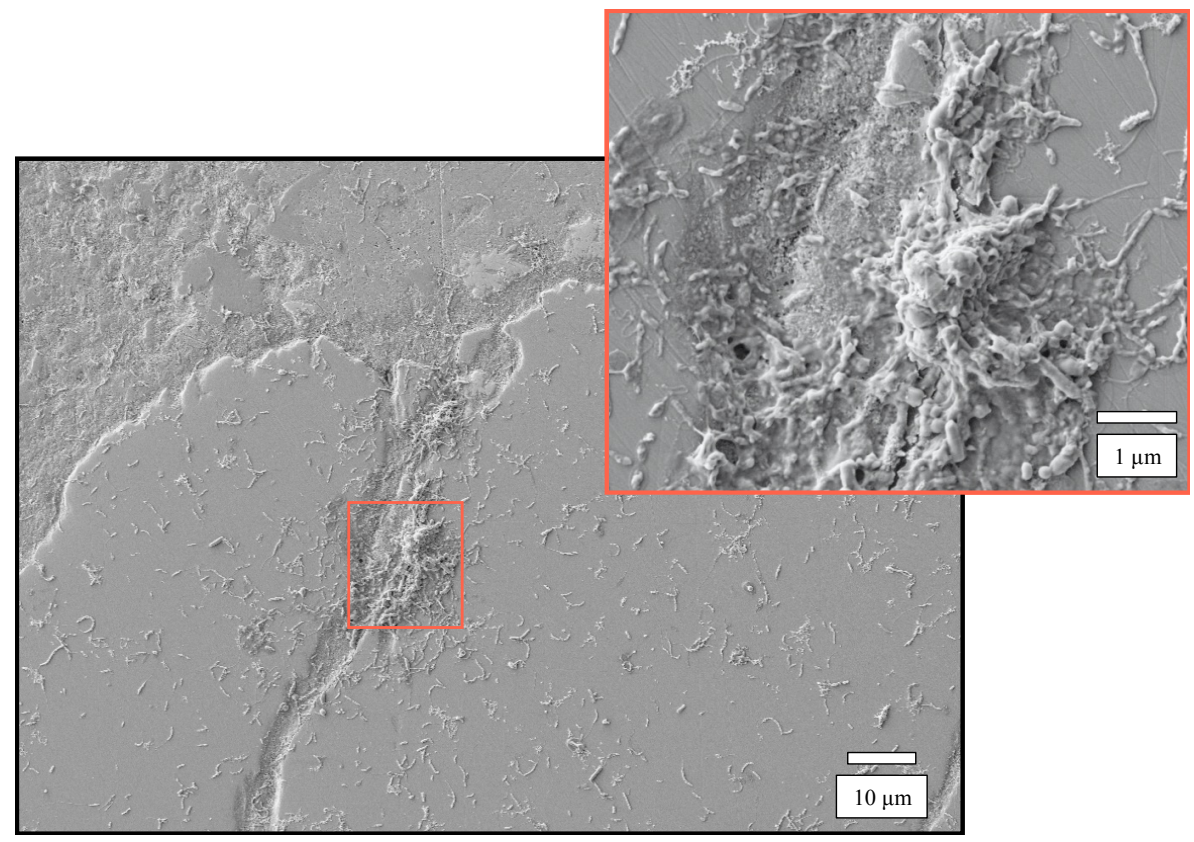

Figure 2 - SEM micrographs showing colonization/growth patterns and population density after 2 months; highlighting the bacterial monolayer and a microcolony (inset). 
High resolution scanning electron microscopy revealed that growth occurred via the development of complex biofilms consisting of a network of pilus-like appendages that connect cells to one another and to the kimberlite surface. These structures provide enhanced attachment to solid reactants in this system, thereby overcoming the spatial barrier created during secondary mineral precipitation and may act as catalysts for low-temperature serpentinization via these putative nanowires, pulling elelctrons directly from the kimberlite (olivine) surface (compare reactions 1 and 2).

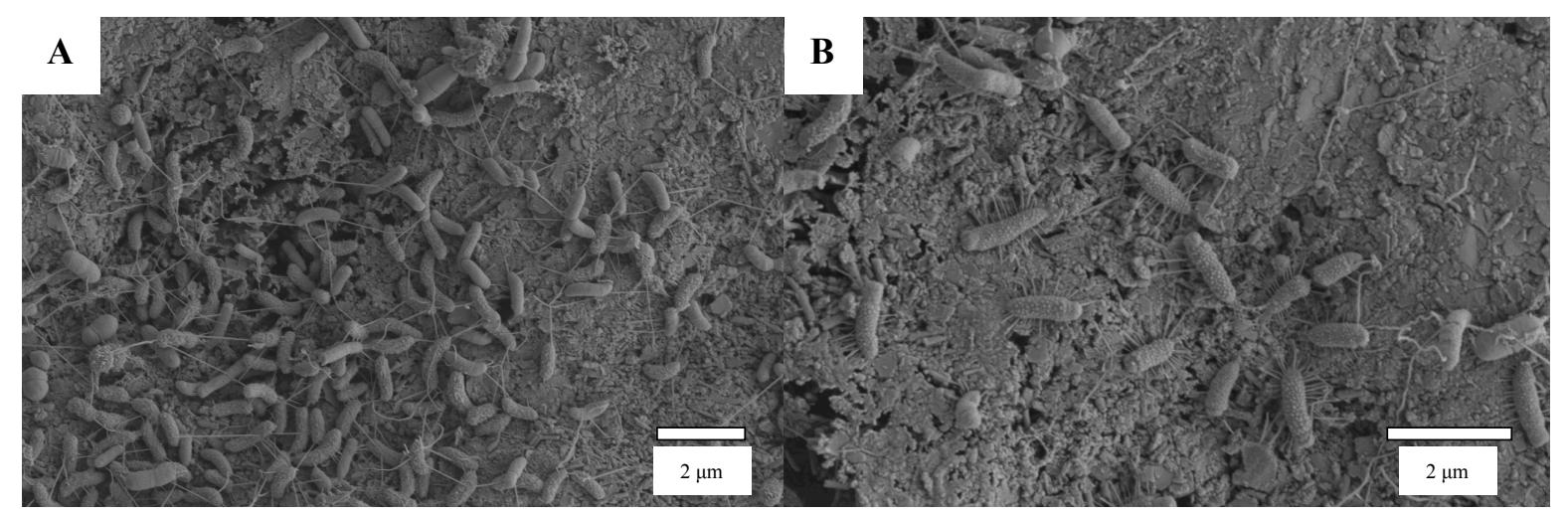

Figure 3 - (A) pilus-like appendages connect cells within the biofilm grown on the kimberlite surface (B) close up image showing a network of cell-cell and extensive cell-mineral connections.

$$
\begin{gathered}
\text { Olivine + water } \rightarrow \text { serpentine + magnetite + hydrogen } \\
\left(9 \mathrm{Mg}_{2} \mathrm{SiO}_{4}+3 \mathrm{Fe}_{2} \mathrm{SiO}_{4}\right)+14 \mathrm{H}_{2} \mathrm{O} \rightarrow 6 \mathrm{Mg}_{3} \mathrm{Si}_{2} \mathrm{O}_{5}(\mathrm{OH})_{4}+2 \mathrm{Fe}_{3} \mathrm{O}_{4}+2 \mathrm{H}_{2} \\
\left(9 \mathrm{Mg}_{2} \mathrm{SiO}_{4}+3 \mathrm{Fe}_{2} \mathrm{SiO}_{4}\right)+14 \mathrm{H}_{2} \mathrm{O} \rightarrow 6 \mathrm{Mg}_{3} \mathrm{Si}_{2} \mathrm{O}_{5}(\mathrm{OH})_{4}+2 \mathrm{Fe}_{3} \mathrm{O}_{4}+4 \mathrm{H}^{+}+4 \mathrm{e}^{-}
\end{gathered}
$$

Kimberlite provides all of the nutrients necessary to support the growth of bacteria, enhancing kimberlite dissolution. Growth of these bacteria contributed to a weathering front extending up to 100 $\mu \mathrm{m}$ into the kimberlite matrix demonstrating that kimberlite can be weathered in situ with the aid of bacteria.

\section{References}

Hattori K, Hamilton SM (2008) Geochemistry of peat over kimberlites in the Attawapiskat area, James Bay Lowlands, northern Canada. Appl Geochem 23:3767-3782.

Sader JA 1Hattori KH, Kong JM, Hamilton SM, Brauneder K (2011) Geochemical responses in peat groundwater over Attawapiskat kimberlites, James Bay Lowlands, Canada and their application to diamond exploration. Geochem: Explor Environ Anal 11:193-210.

Sader JA, Hattori KH, Brauneder K, Hamilton SM (2013) The influence of buried kimberlite on methane production in overlying sediment, Attawapiskat region, James Bay Lowlands, Ontario. Chem Geol 360-361:173-185.

Southam G, Saunders JA (2005) The geomicrobiology of ore deposits. Econ Geol 100:1067-1084.

Stevens TO, McKinley JP (1995) Lithoautotrophic microbial ecosystems in deep basalt aquifers. Science 270:450-454.

Stevens TO, McKinley JP, Fredrickson JK (1993) Bacteria associated with deep, alkaline, anaerobic groundwaters in southeast Washington. Micro Ecol 25:35-50.

Wanger G, Onstott TC, Southam G (2008) Stars of the terrestrial deep subsurface: A novel 'starshaped' bacterial morphotype from a South African platinum mine. Geobiol 6:325-330. 